\title{
Blind Politics of Ambition: Shale Gas in Poland
}

\author{
Stephanie Niemuth / Sophie Westphal \\ Technical University of Applied Sciences, Wildau, Germany
}

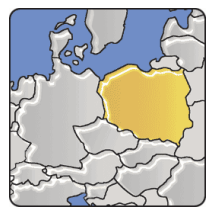

Abstract. Ever since the impacts of the shale gas revolution in the US have unfolded their measurable effects - as significantly declining natural gas prices - impressive euphoria among those states which are identified to bear high potentials of unconventional gas is widely spread. As for Poland, essentially linked to the hope of profitably producing shale gas is the political will to strive for independence from Russian energy supply and thus, enhance energy supply security. Hence, liberalizing its gas market shall effectively contribute to foster economic developments in the field of unconventional gas exploration and production. Moreover, attempts are made to encourage particularly foreign investors for the reason of expertise - to enter the Polish gas market by amending and expanding legislation in favour of this development. Legislation efforts, however, intend to preserve comprehensive governmental control capabilities. In addition, arising environmental concerns are being tried to handle either by campaigns of clarification or political blockade to any legislation that potentially threatens the progress on unconventional gas in Poland. Poland not only faces crucial challenges in terms of diminished estimates on profitably recoverable shale gas volumes but rather in terms of an escalating atmosphere of uncertainty for investors - regarding the much criticised new legislation as well as an upcoming diminution of societal support.

Keywords: energy, energy policy, fracking, hydraulic fracturing, natural gas, Poland, regulatory politics, shale gas, tax, unconventional gas

Authors: Stephanie Niemuth and Sophie Westphal are M.A. candidates in the European Management program at Technical University of Applied Sciences, Wildau, Germany.

\section{Introduction}

In a world heavily depending on resources - in fact, being addicted to them - the possession of resources is irrevocably linked to power. Resources are typically characterized by scarcity, which implies that there are only limited volumes and amounts available. This is what defines their value monetarily but also politically. Hence, a country being rich in resources is able to essentially dominate and direct political decision making processes: Negotiation partners typically strive to achieve outcomes which are at best interests for all parties involved. However, as soon as economical disadvantages must be feared, the sustainability in defending an argument will certainly tend to weaken although the fundamental interest itself might still be given. In consequence, resources enable a country to demonstrate political power. This rather general resource-power interdependency can thus be transferred to the issue of exploration and production of unconventional gas as follows: Strongly related to the discovery of unconventional gas is the political hope for energy independence as well as - in consequence - an increase in political power.

With this in mind, the article shall illustrate the current status quo of unconventional gas exploration and production in the Republic of Poland. It points at the prospected socio-economic impacts and the legal framework applied, highlights the recent developments in terms of shale gas exploration and production, further outlines the relations between government and business and finishes with an analysis of the Polish way of dealing with upcoming opposition. The article concludes with an outlook on the potential future of shale gas in Poland.

\section{Anticipated Socio-Economic Impacts of New Gas Production}

The issue of unconventional gas and its related debate across Europe and within the European countries themselves, mainly results from an apparently successful production of unconventional gas in the United States of America. This 'shale gas revolution' (Kosciuszko Institute 2012: 15) has impressingly contributed to the dropping of natural gas prices in the US (Kosciuszko Institute 2012: 15). The reason for this decline in prices can certainly be found in an increased independence from foreign gas supply and thus in an increased domestic production of natural gas. The Republic of Poland however in its natural gas consumption is characterized by being strongly dependent on energy imports: Foreign supply meets $63 \%$ of the total consumption of natural gas (KPMG 2011: 38). Out of the overall natural gas imports approximately $90 \%$ are provided by just one supplier which is Russian gas (KPMG 2012: 39).

Moreover, with regards to the graph displayed below it can be clearly seen that there is a persistent tendency in an increasing demand for natural gas for consumption purposes over the past three decades. Since shortly after 1990 - after the breakdown of the Soviet Union and the fall of the Iron Curtain - the development of the natural gas consumption in Poland has more or less continuously soared. Periodic declines are mainly linked to eco- 
nomic crises - the last one in the years 2008/2009 and the global financial crisis (KPMG 2012: 40).

In addition, Poland's energy mix is commonly considered unsatisfactory in terms of energy security (KPMG 2012: 39). Concerns on energy security center particularly on the question of 'stable and continuous natural gas supply at competitive prices' (Kosciuszko Institute 2011: 119). This, due to the fact mentioned before - where after $90 \%$ of the total natural gas imports is constituted by Russian gas. It is argued that the risk of geopolitical factors in terms of gas supply stability will continue to exist: As for Poland, those risks arise from the fact that its natural gas is delivered via Belarus and partly Ukraine which each by themselves once in a while face conflicts with Russia (Kosciuszko Institute 2011: 120). Hence, when Poland was assessed to bear the "most significant potential for shale gas" (Kosciuszko Institute 2011: 31) among Europe, Polish government considered this detection as the initial moment to 'diversify (...) and expand the network of natural gas supply' (KPMG 2012: 39). Proceeding from this general introduction to the Polish energy portfolio the abstract further points at prospected impacts of the gas market liberalization and the potential socio-economic costs and benefits - arising from the development of the shale gas extraction sector.

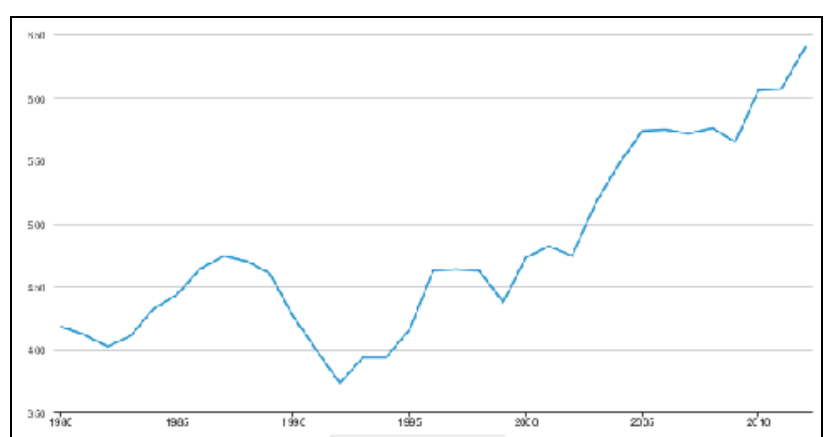

Figure 1: Poland natural gas consumption (1980-2012), in billion cubic feet. Source: US Energy Information Administration (2013).

\section{Gas market liberalization}

The use of natural gas as a source for the primary energy within the Polish energy mix ranges in the third place. However, compared to the share of coal and oil, the supply of natural gas is still relatively limited: In 2009 the share of natural gas of the total primary energy supply amounted to $12.7 \%$ only.

Yet, in accordance with a continuously increasing demand in terms of natural gas consumption the prospected importance of natural gas is 'predicted to grow significantly' (Kosciuszko Institute 2011: 119). Hence, liberalizing the Polish gas market appears to be most essential with regards to the development of a shale gas extraction sector. Efforts in this field mainly comprise a liberalization of prices and the establishment of a competitive market.

As for the liberalization of prices, the Polish gas market can literally be characterized as a monopoly: The dominating company PGNiG SA 'exercises a monopoly over all links of the gas value chain' (Kosciuszko Institute 2011: 119) which - in consequence - leads natural gas being subject to tariffs (Kosciuszko Institute 2011: 121). Tariffs however, result in negative effects to occur: Using the profits from the domestic natural gas production to subsidise imports leads to the generation of end user prices below the market price. Therefore, a certain demand needs to be interpreted as artificial - such a demand hinders the economy to perceive price signals that are of essential importance to efficiently allocate scarce resources (Kosciuszko Institute 2011: 121). In addition, the mentioned pricing scheme results in
PGNiG SA demonstrating rather low intentions to increase the domestic production of natural gas as this would certainly imply 'further subsidizing of imported gas rather than increasing its profits' (Kosciuszko Institute 2011: 121). On the contrary, due to the fact that the level of tariffs for gas is determined on the basis of costs, a distinct lack of motivation for PGNiG SA can be outlined to reducing those (Kosciuszko Institute 2011: 121-122). Moreover, prices for the end user being lower than the market price, hardly generates signals of an attractive market. It thus prevents potential suppliers to enter the Polish gas market and for that reason further consolidates the existing monopoly (Kosciuszko Institute 2011: 121).

Yet, liberalizing the domestic gas prices would lead to a more realistic demand and thus enforce suppliers to naturally set their prices as - competitively - low as possible, to maintain their supply volume (Kosciuszko Institute 2011: 121).

As for the establishment of a competitive market, this is assumed to be achieved through a large number of entities operating on the Polish gas market - once the liberalization of prices has boosted its attractiveness (Kosciuszko Institute 2011: 123). Generally, a large number of entities operating on one market represent an economic characteristic - a prerequisite in the Polish case - for a competitive market: Granting all market participants access to various suppliers certainly facilitates competition among them in order to succeed and persist on the respective market. With regards to an impressing number of companies operating in the unconventional gas exploration industry it is to be assumed that 'there is no real danger of monopolization or cartelization aimed at fixing prices' (Kosciuszko Institute 2011: 123). In addition, prices observed on the New York Mercantile Exchange reveal the perfect competitiveness of the US market. Due to a similar structure of the unconventional gas exploration industry in Poland, these findings strongly indicate chances of an equal development possibly to take place in Poland as well (Kosciuszko Institute 2011: 124).

Hence, competition in general - may it among domestic or under the presence of foreign suppliers - can be considered a powerful 'source of pressure' (Kosciuszko Institute 2011: 124) to enforce optimization and price competitiveness.

In conclusion, the current way of dealing with gas imports as a rather political purchase - as it requires an intergovernmental agreement - leads to a pricing scheme that adds on an unquantifiable element to the final gas price: The political factor. Thus, the real import costs are not known and can therefore not be made transparent (Kosciuszko Institute 2011: 119). Promoting the 'unconventional gas revolution' (Kosciuszko Institute 2011: 120) however can effectively contribute to develop a 'competitive and commercial gas market in Poland' (Kosciuszko Institute 2011: 120). This, in turn, will finally enable the market to apply to the principle of economic optimization (Kosciuszko Institute 2011: 119).

\section{Socio-economic costs and benefits}

Besides highlighting the various benefits which ought to be arising from developing the unconventional gas exploration and production sector, this development also contains social costs that are likely to occur. In accordance with the experience made in the US, those issues to direct attention to mainly comprise: damaging of public transport infrastructure due to 'heavy loads transported on trucks' (Kosciuszko Institute 2012: 13), noise and falling of prices for properties in neighbouring areas to industries or exploration and production of shale gas (Kosciuszko Institute 2012: 13). Knowing about these social costs is inevitable for local communities as well its inhabitants to not only be aware of their rights but rather to be able to take over a distinct negotiation position with regards to claiming for compensation and other 
benefits. In abstract six of this paper - Public Policy - the Polish government is putting politics ahead of every other business - a distinct focus will be put on issues in that field. However, it can be assumed that the socio-economic benefits to be expected in the affected drilling areas will generally exceed the incurred inconveniencies and costs (Kosciuszko Institute 2012: 13).

As for the anticipated benefits, these mainly contain benefits arising from dropping gas prices as well as benefits affecting the local labour market.

Irrevocably linked to the development of activities in terms of the unconventional gas sector is the expectation of a 'reduction of natural gas prices' (Kosciuszko Institute 2012: 13). In the light of Poland facing the highest gas prices in Europe, a drop in prices implies impacts of vital importance for the Polish economy in general: To satisfy an increasing demand for natural gas in the fields of energy, chemistry and private households, access to cheaper domestic gas must be made available and in turn, may positively influence the 'dynamism of economic growth' (Kosciuszko Institute 2012: 14) - which may moreover be reflected by a higher national GDP (Gross Domestic Product). In addition, the assumed dimensions of positive impacts of a development of the unconventional natural gas sector on the economy appear to be threefold: 'direct, indirect and induced' (Kosciuszko Institute 2012: 14). Expanding the domestic production will require new gas power plants to be built or rather install combined heat and power plants. Those heat and power plants are typically based on the co-generation principle and therefore boost the energy efficiency as electricity does not need to be transported far anymore (Kosciuszko Institute 2012: 14). In consequence, enhanced energy efficiency might cause electricity prices to decline. Lower electricity prices that then result in establishing a competitive advantage of Polish firms which in turn, might expand their businesses (Kosciuszko Institute 2012: 14).

As for the prospected impacts on the local job market, these prospects distinctively depend on the succeeding realization of one or the other scenario. In any case however are those projections purely positive as 'the functioning of shale gas production facilities will increase the probability of job creation' (Kosciuszko Institute 2012: 15). Simply the forecasted quantitative effect varies along the scenarios: The minimum growth to be achieved as of the pessimistic scenario within the upcoming ten years would equal approximately 120,000 new jobs. Yet, employment might also accumulate by around 190,000 as of the optimistic scenario (Kosciuszko Institute 2012: 15).

In conclusion, the presented analysis clearly outlines the underlying political hopes for energy supply security in the first place but in fact, prosperity in the second place by further developing unconventional gas exploration and production in Poland.

\section{The Legal Framework}

With respect to the idea of fracturing unconventional gas from the shales as an apparently new process, the Republic of Poland currently 'lacks separate legal regulations' (Kosciuszko Institute 2011: 175) that are directly addressing operations in terms of 'prospection, exploration and production of unconventional gas' (Kosciuszko Institute 2011: 175). Hence, as for any business activity to be commenced in that field there are the same regulations applicable as for those of conventional natural gas (Kosciuszko Institute 2011: 175). The Ministry of the Environment thereby represents the most important political body in granting concessions (KPMG 2012: 43). Moreover, with the beginning of the year 2012, new legislation regulations have come into force. In principle, the obligation for an operator to 'obtain separate concessions' (Kosciuszko Institute 2011: 189), remains un- touched. Nevertheless, the procedure itself in terms of granting a concession has changed - it envisages mandatory tender procedures as of each area met by the concession. The fundamental aim is to achieve greater competition among those businesses that are applying for such a concession (Kosciuszko Institute 2011: 189).

\section{The procedure of obtaining a concession}

The underlying legal frameworks when it comes to granting a concession are the Geological Law as well as the Freedom of Business Activities Act. However, due to missing information packages providing detailed information on statutory requirements on the one hand and an official form of applying for a concession on the other hand, each business operator literally prepares its own application form (Kosciuszko Institute 2011: 176). Yet, according to the new legislation a separate chapter has been added which exclusively identifies 'the issues related to the organization of a tender procedure' (Kosciuszko Institute 2011: 190). Those issues contain information on the terms of the procedure and its selection criteria, outlines the scope of information which needs to be included 'in a notice of a procedure' (Kosciuszko Institute 2011: 190) and highlights the obligations of the Minister of the Environment for communication (Kosciuszko Institute 2011: 190).

As for the filing of an application, it must be clear to the operator that an application will have better chances to effectively pass the application process, the more 'thorough and exhaustive' (Kosciuszko Institute 2011: 176) it is. As the process of concession granting depends to a great extent on exactly that exhaustiveness of the submitted application, they 'should be filed in due advance before the intended date of commencement' (Kosciuszko Institute 2011: 176). In any case, the final concession will be granted by the Minister of the Environment. However, appropriately cooperating public authorities are able to issue opinions, approvals as well as refusals by themselves to the respective Minister (Kosciuszko Institute 2011: 176). The Minister himself on the other hand is according to the new legislation required to acquire those opinions, approvals or refusals prior to the actual opening of the tender procedure (Kosciuszko Institute 2011: 190).

Opinions issued may be used by the Minister as complementary materials whereas a refusal might identify a fundamental reason for the final refusal by the Minster to grant a concession. Nonetheless, both opinions and refusals are not of binding character (Kosciuszko Institute 2011: 176). An approval in contrast, 'mandates the granting of consent for the operator to proceed with the contemplated licensed activities' (Kosciuszko Institute 2011: 176). Although not further specified whether or not an approval given by those authorities possesses binding character, it is to be assumed that an approval might not result in an ultimate refusal by the Minister.

\section{Mandatory and environmental components}

Concessions may be granted for different types of activities such as "prospection or exploration or production of minerals from fields/sites' (Kosciuszko Institute 2011: 177). Apart from those activity types, both the Geological Law and the Business Activities Act require certain mandatory elements that need to be met by an application (Kosciuszko Institute 2011: 177):

- The applicant must define type and scope of those business activities that shall be met with the concession to be granted.

- In addition, the applicant's title - if existing - must be proven to the use of geological information to the site where the activities ought to be pursued. If a title does not exist so far, an intention to acquire the respective one must be given. 
- The duration of the concession including the specification of the supposed date to commence business activities needs to be presented.

- To indicate that activities are to be performed properly, proving of sufficient financial resources available is required.

- Once the application is filed, a stamp duty needs to be paid.

In addition to the aforementioned legal frameworks, a third framework becomes applicable already prior to the actual opening of the tender procedure: As of the environmental legislation, an environmental conditions decision is required (Kosciuszko Institute 2011: 180, 190).

In cases of licensed activities that 'are qualified as having a significant potential impact on the environment' (Kosciuszko Institute 2011: 180), the environmental legislation demands both an environmental impact assessment and all installations being subject to investment inspection. Those inspections are being conducted by the environmental protection inspector who is in charge of ensuring compliance with environmental protection requirements (Kosciuszko Institute 2011: 180).

In the course of obtaining an environmental conditions decision, all environmental impacts that are likely to occur are identified. Besides, some business activities may also require an impact assessment to be conducted in order to minimize the identified threats to the environment (Kosciuszko Institute 2011: 180).

The new legislation has set forth further requirements for the operator to meet: It is in the responsibility of an operator to identify areas that are 'covered by special forms of protection' (Kosciuszko Institute 2011: 190). Those special forms of protection may include the protection of nature or the protection of historical monuments. Additionally, any negative impact on the natural environment by conducting the intended business activities needs to be backed by specifying methods how to prevent and rectify those (Kosciuszko Institute 2011: 190-191).

\section{The right of a business operator to produce}

Certainly, the extent to which an operator is guaranteed the succeeding right to produce after finishing the exploration on a special site, 'appears to be a major issue under the New Legislation' (Kosciuszko Institute 2011: 191). It must be noted that priority rights do not explicitly exist with regards to production concessions. However, it is the Minister's right to grant a concession bearing a 'pre-emptive right' (Kosciuszko Institute 2011: 191). It is then that the operator is basically granted a 'valid claim against the State Treasury' (Kosciuszko Institute 2011: 186). This claim implies that the operator who has conducted the exploration of the mineral deposit and documented its geological specifics 'has priority (...) over other operators' (Kosciuszko Institute 2011: 186) with regards to the respective deposit.

Moreover, the Geological Laws enacts an exclusive right for the operator to' use the information (...) obtained for the purpose of production of minerals' (Kosciuszko Institute 2011: 187) for a period of five years (Kosciuszko Institute 2011: 191). However, it is not clear if after the publication of the submission of an application for a concession for production purposes, other interested business operators would be allowed to file an application themselves. This uncertainty arises particularly with respect to the fact that each type of a concession is subject to a separate tender process. In any case, for the period of validity for the operator with the exclusive right of using its geological information obtained, the Minister 'will not be able to grant a concession to any other operator' (Kosciuszko Institute 2011: 191).

Hence, the transition process - proceeding from the exploration to the production stage - 'is [basically] secured in favour of the business operator who explored the deposit in question' (Kosciuszko Institute 2011: 187).

\section{From Euphoria to Realism}

The years 2006 and 2007 are considered to be the initial starting points of the development of a potential shale gas industry in Poland. Within these years, the first 11 licenses have been granted to four different companies by the SCT (deputy minister for the environment) on behalf of the Polish State Treasury. This procedure is a usual one in Poland anchored in the local Geological and Mining Law. At this stage licenses have been awarded very cheap without any sufficient guarantee of control with regard to the exploration. The Polish government asked for a price of around 100 Euros per square kilometre (Jędrysek, 2013).

Subsequently, estimates of 5.3 trillion cubic meters natural gas reserves in Poland conducted by the US Energy Information Administration (EIA) in 2011 promptly resulted in a huge enthusiasm by both Polish politicians and national and international operating firms assuming a beneficial business in Poland. The estimated number equates nearly 900 times the Polish society's consumption in 2010 (McClatchy, 2013). As a consequence, Poland became the country with the largest shale gas resources within the EU and started to grant licenses to search for shale gas to a number of companies.

It is to emphasize again, that for Poland, such developments can have crucial influences on energy security. Coloured by a constant distrust of Russia with regard to energy resources energy security has a very special meaning for Poland. Prospects in this industry therefore strongly impact their interest in shale gas.

In the light of interest three main basins can be determined the Baltic Basin in the north, the Podlasie Basin in the east and east-central and Lublin located in the southeast of the country (Johnson \& Boersma, 2012). The euphoria about the shale gas reserves have promptly been damped in a slight way when in 2012 new estimates with stricter methodologies have been published by the Polish Geological Institute (PIG) and the US Geological Survey. Accordingly, initially estimated figures decreased by a factor of seven to fifteen (Press Europ, 2012). This surprising development let potential operation companies question whether the investment of huge sums in test drillings still shows economically beneficial prospects for them. To achieve clarity and confidence in this manner, many experts in this field advised to conduct exploratory drillings as an only option to acquire first important information on the geological potential.

At this point, it is to mention that shale gas exploration is a completely new industry for Poland. As the country is not able to prove sufficient hands-on experience, appropriate technology or even enough capital, it strongly depends on the expertise and capital of foreign firms in fracking - the key method for shale gas extraction, in particular North American companies which are supposed to be the most experienced ones. Consequently, the Polish government is keen to attract foreign firms in order to receive this urgently needed information.

According to a leading Polish think tank, the Kosciuszko Institute, Poland would potentially drill an average of 500 wells per year (McClatchy, 2013). Media Reports and other sources show, that the initially assumed situation, however changed. In summer 2011, gas-exploration companies planned to drill around 120 test wells within the coming years in order to assess if Poland effectively has the largest reserves of shale gas (The Economist, 2011). Nevertheless, only 33 test wells have been drilled over a period of three years and there is still no concrete result available. So far, 111 exploration concessions have been awarded to about 30 companies, both state-owned and international, on a territory of more than 35,000 square miles, nearly a third of the country (McClatchy, 2013). A serious problem which Poland is currently confronted with is that major operating companies simply abandoned exploration in the last months. In October 
2012, the US oil company ConocoPhillips opened up that it will not start operating in the eastern basin of Poland as the gas is considered to be of less quality compared to the western basins. Already three weeks prior to this announcement, also ExxonMobil decided to pull out from Poland based on previous unsuccessful tested wells that lack economic promises from the point of view of the company (PUNCH, 2012). At the same time, there were additional speculations about the Canadian Energy Company Talisman objecting to sell off its Polish exploration licenses (McClatchy, 2013). In May 2013, the company finally left the Polish business. At the same time, Marathon Oil announced to sell its operations by 2014 , as its Polish licenses are supposed to be less beneficial (Warsaw Business Journal, 2013). A year later, Total of France would also not renew its exploration license (Goclowski \& Kahn, 2014).

With these incidents, the uncertainty about the country's shale gas future started to increase instead of the other way around as it was initially objected by Poland. Hence, Poland still does not have any reliable information on the potential to commercially produce shale gas. Still the quality of the gas and the extraction costs are widely unknown. Economic, political and environmental factors still left the country and its future planning with regard to unconventional energy in an uncertain situation. That puts more and more pressure on the government to undertake appropriate actions to shape the situation into a positive fashion. Reuters estimates that not even one of the currently 40 operating test wells will start to produce gas before 2015 (Reuters, 2013).

\section{A Keen State-Business Relationship}

The government-business relationship in the context of shale gas operations is currently accompanied by a dense tension between investors and the country. It is not only the growing uncertainty about the development of a shale gas industry in Poland and therefore the long desired independence from Russia that puts pressure on the Polish government, on the other side an uncertain and therefore unattractive legislation from an investor's perspective have been the main sources provoking such a tension between state and business. In the focus of conflict, is the proposal of a new shale gas regulation.

It is to mention, that all geological deposits in Poland are stateowned. Thus, the state strives for transparent approaches with regard to license ownership and the exploration process and also controllability. After granting the first licences in 2006/07, thus, Polish government initially aimed to develop new regulations and new laws which include beside other issues to establish a new special state agency. Today, Poland is still in the planning phase to set up the National Operator for Energy Resources, called NOKE (Jędrysek, 2013). In the frame of the new proposed shale gas law, this national operator represents one reason for the keen relationship between state and investors. The reason behind is, that NOKE will have the right of first refusal to buy energy concessions on the secondary market and at the same time it will have stakes in the licenses. For investors this means being confronted with higher costs and risks, as operating as both an investor and a regulator is a conflicting situation of interests (aktivist.pl, 2013).

The main interests of investors are basically to have future security and stability. Generally, an investor would not start operating in such a business without being guaranteed any beneficial and reliable regulations. The state, however directs the law to government controlled geological and mining companies, such as PGNiG that is therefore currently the only active operator in Poland (Jędrysek, 2013)._According to the Polish Exploration and production Industry Organization (OPPPW), the new pro- posed hydrocarbon law may rather appear as an obstacle for speeding up the commercial production of natural gas than as a supporter. The Polish lobby group argues against the planned state-controlled company NOKE that is aimed to operate as a regulator for the industry. Referring to the new law proposal, this firm will hold small equity stakes in each concession. The lobby group represents the view that this kind of state intervention will on the one hand further extend the decision-making process in terms of time and on the other hand it also additionally limits available equity for other investors (E\&P News, 2012).

Media reports demonstrate further conflicts within the new shale gas regulation proposed by the government that do foster the tension between state and companies. In a consultation process in March 2013, shale gas firms criticized the uncertainty which arises based on the law for them. The conflict particularly refers to the rule of establishing a tender for extraction licenses after test drills have been concluded. This leaves the companies uncertain about if they are allowed to generate profit within the same license they have initially invested in for test drillings (aktivist.pl, 2013). Moreover, the new regulations tend to be too bureaucratic in the eyes of investors which makes operating in Poland very unattractive for them.

The government is in a weak position as it needs to attract foreign companies in order to speed up the development of the shale market. Moreover, investors need a stable legal environment and clear regulations that gives them the benefit of prediction. In this way they are able to conclude future costs and benefits and hence evaluate the potential risks. Being in a good bargaining position, companies consequently try to put pressure on the Polish government. A report from the Warsaw Business Journal demonstrates how firms urge the state to change regulations immediately. According to this report, shale gas firms have already been waiting for any change in law for three years. In the focus of tension between government and investors is the regulation introduced in 2010 that defines conditions for conducting drills deeper than 1,000 meters, what particularly Chevron aims to do. The conflicting issue deals with new permissions required for extending existing boreholes. Though Chevron claims in an official statement to not plan to withdraw from Poland, a Polish member of the European Parliament takes the existing risk very seriously and assumes that Chevron will be the fourth company withdrawing from Poland if the country will not conduct any change in law until the end of 2013 (Warsaw Business Journal, 2013). Considering that at this time several countries like for instance France decided to ban hydraulic fracturing due to environmental risks, this is indeed supposed to be a serious problem for Poland, as the European Union might create regulations that will influence the potential development of a shale gas industry in Poland in a negative way.

As time was running in April 2013 and pressure on the state increased, the Polish government finally proposed regulations on shale gas exploration and production accordingly. Thus, the law lightens effort in bureaucratic issues with regard to environmental procedures which is aimed to encourage companies to conduct exploration works. Hence, to give an example, there is no additional permitting procedure required for the case of drilling wells deeper than actually agreed on (Cleantech Poland, 2013). In June 2013, another new version of the geology and mining law draft has been announced by the Polish Ministry of Environment to make a further step to meet the objectives of new investors concerning clarity. The established operator NOKE shall cap profit participation at 5 percent proportionally to costs (Cleantech Poland, 2013). In an interview with Bloomberg in June 2013, the Polish Treasury Minister Karpinski additionally intended to hush doubting investors that the shale gas business will remain in the primary focus of the state. According to him, Poland's current priority is to focus on increasing hydrocarbon extraction. That 
means that the government is keen to allocate all financial assets and investments to this project. Accordingly, there is a program called Polish Investments that provides Poland's key investment projects with loans and guarantees from the state bank BGK which can potentially support the plans (Ministry of Treasury, 2013). As Poland does not have sufficient financial resources in order to be able to finance the shale gas exploration, local companies like PGNiG are additionally negotiating with foreign partners about works at their shale gas licenses. These are primary investors from North America (Natural Gas Europe, 2013).

By means of the development of this conflicting relationship between government and investors and the resulting actions by the state, one can identify an incremental style by the government. Decisions to meet the interests of investors are rather based on a try-and-find-out approach than on rational grounding.

\section{Putting Politics Ahead of Business}

While the Polish government is strongly focusing on shaping the relationship with its potential investors in a positive manner by changes in regulations, environmentalists and inhabitants, in particular farmers also raise their concerns about the fashion of action by the state and the new regulation. The basic problem is that the government is simply too enthusiastic about the potential freedom from Russian imports. In its ambition and enthusiasm to achieve independence from Russia the government considers important aspects in a so called tunnel vision which narrows their window of opportunity and blindly releases protests that harm the trust in the local authorities. Protests not only come from a national level, but also indirectly from the European Parliament when it comes to environmental harms.

In order to make the public aware about the potential environmental costs and risks associated with shale gas, the European Commission introduced three huge reports about impacts of shale gas on markets, environment and climate in September 2012. Within the frame of the environmental impact study, the Commission stated that shale gas extraction is generally more harmful to the environment than conventional gas extraction. On the other hand, the report on climate impact showed results in favour of shale gas extraction. Accordingly, greenhouse gas emissions from shale gas are supposed to be two percent to ten percent lower than emissions from electricity generated from conventional pipeline gas and seven to ten percent lower than that from LNG. Further environmental risk areas associated with the extraction method of shale gas that environmentalists and particularly inhabitants and farmers fear, are air and noise pollution, groundwater and surface water contamination and biodiversity. This has risky influences on the environment and health of individuals (Johnson \& Boersma, 2012).

After EU energy commissioner Günther Oettinger made it clear in 2011 that the European Commission is debating about a European regulatory framework on shale gas production, Reuters assumed that Poland will veto any EU anti-shale gas moves that potentially limit the industry's development in the country (Reuters, 2011). As predicted, in April 2012 a Polish MEP submitted a report vetoing new regulations on shale gas and claiming that they are not necessary (Polskie Radio, 2012). Consequently, according to a press release in November 2012, Poland required a moratorium on the rock fracturing technology used in shale gas production in the entire European Union, but the Parliament responded with rejection of this inquiry. In a press conference, Prime Minister Donald Tusk told "We will be persistently trying to show Europe that production of shale gas makes sense" (Automated Trader, 2012).
The foundation "Czysta Energia" points out that Poland does not play a fair game. On the one hand, Poland does not conduct sufficient environmental studies and on the other hand the environmental offices are not even able to evaluate the projects from an environmental perspective due to non-existent adequate tools to do so (aktivist.pl, 2013). Currently biggest operating companies in the field of shale gas exploration in Poland are stateowned firms like PGNiG, copper miner KGHM or PKN Orlen. The fact that some of them have no experience with energy exploration (BBC News, 2013) shows indication that the Polish government puts politics ahead of industry expertise.

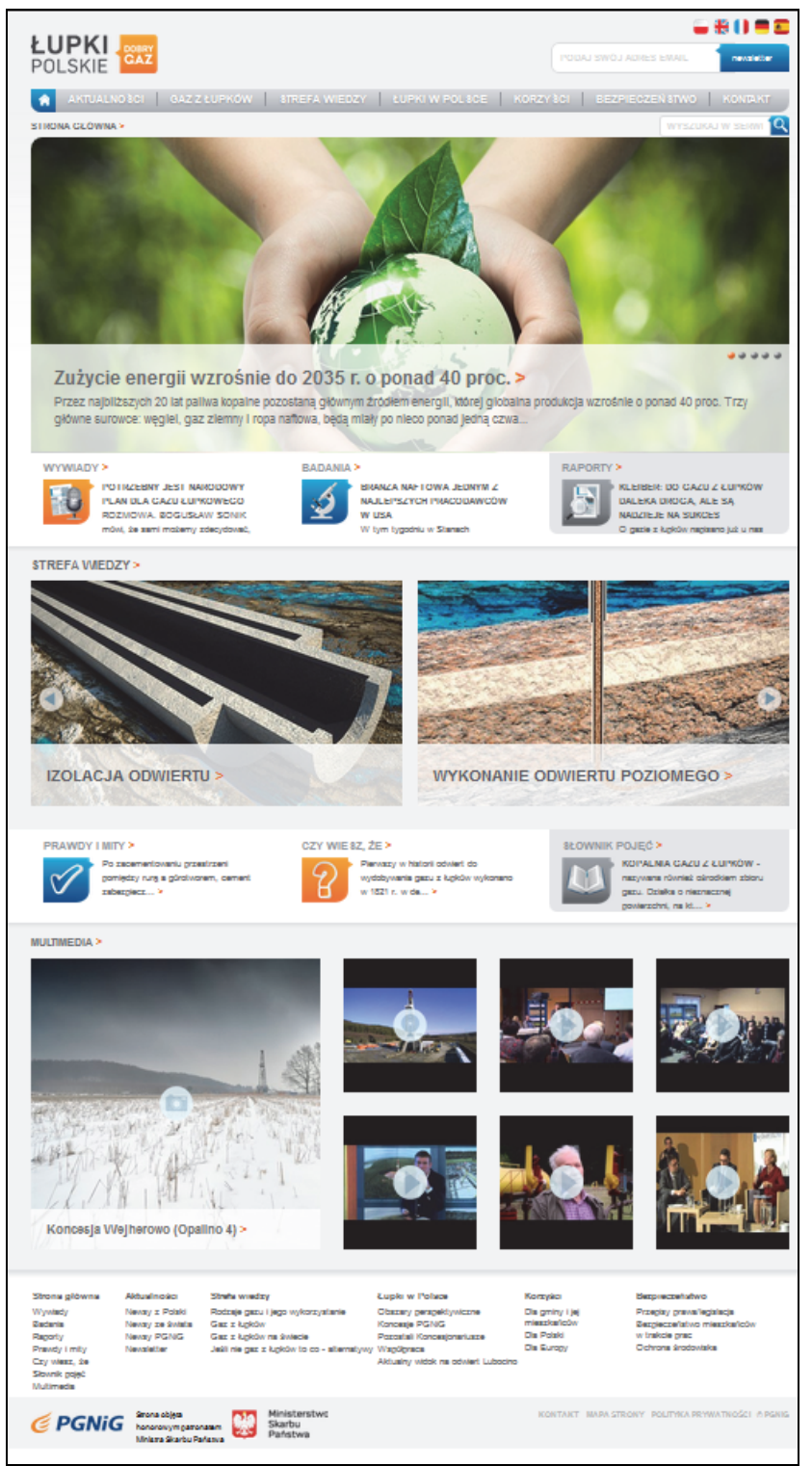

Figure 1. "Polish Gas - Good Gas" website at lupkipolskie.pl It is available in English (polishshalegas.pl), German, French and Spanish, demonstrating a mission to attract international investors but also to take the pro-shale message abroad. The website is managed by PGNiG but co-sponsored by the government.

According to environmentalists, the proposed legislation mentioned above appeared as an attempt by the government to avoid an anti-shale gas movement in advance. Within the proposal in question, environmental organizations only get permission to participate in environmental permitting process, if they have been in existence for at least twelve months (Cleantech Poland, 2013). It seems that the Polish government tries to accelerate its 
exploitation plans on shale gas by limiting and silencing potential internal opposition and minimizing regulations, so that investors are easier to attract. Green opponents, however, actively respond to this approach of the Polish government.

The Polish climate Coalition, which is the largest coalition of environmental organisations within the country, acts against the state by blaming it for acting against democracy and transparency, which is an abuse of civil rights. This movement let Poland shine in a negative light, especially as it damaged trust in the local authorities (Natural Gas Europe, 2013). This might further narrow the window of opportunities for the Polish government, as it shall act in the interest of the society. But if trust is damaged, more protests against will occur more and more which brings Poland not only in a conflicting situation with potential investors but also with its society.

The recent "Occupy Chevron" movement additionally mirrors the problem of a growing mistrust of the civil society in Polish authorities. Since June 2013, local farmers start to protest against Chevron as they fear a huge potential contamination of the farmland. It was the Ministry of Environment that allowed Chevron to conduct tests on leased land, though it has no local permission to undertake such actions. According to "Occupy the Pipeline" farmers now fear uncontrolled fracking operations by Chevron and therefore protest. The company did not complete the permission procedure. This indicates again that the Polish government is disposed to ignore certain regulations and procedures in order to achieve the goal of being independent from Russia (Occupy the pipeline, 2013).

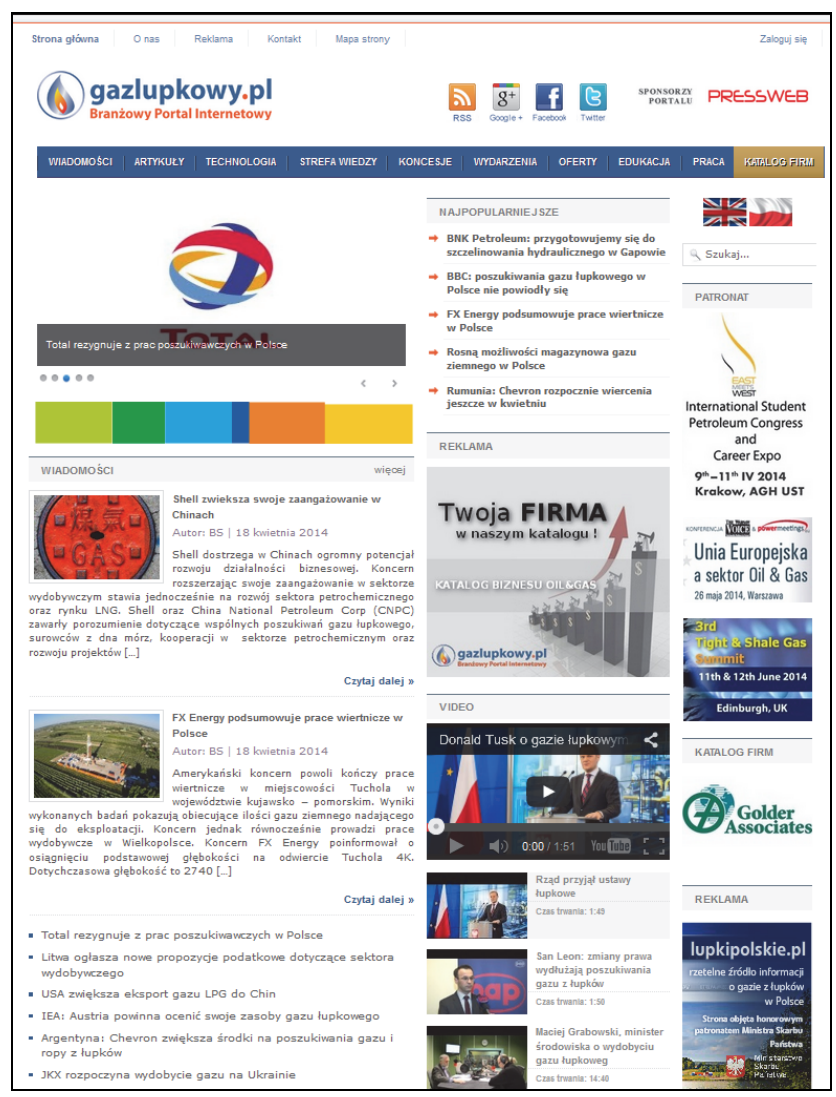

Figure 2. "Let's Talk About Shales" campaign website, gazlupkowy.pl, also published in English (polishshale.pl).

In July 2013, the Polish government responded to critics in an attempt to rebuild trust of the society with the campaign "Let's talk about shales". This campaign primary focussed on local residents near shale gas exploration sites but also on all stakeholders, aims to give the opportunity to establish a dialogue with the society and in this way gives them a chance to raise their opinion concerning shale gas extraction, especially in northern Poland. "Let's talk about shales" includes a website with online consultations and also the organization of public hearings. The website basically provides informative material including both technical and environmental aspects of shale gas operations. The campaign will last until the end of 2013, when representatives of the Ministry of Environment plan to develop a public document that reveals the most important needs, expectations, hopes and concerns of all stakeholders and necessary actions to undertake in the future (Ministry of Environment, 2013).

This campaign, however, should be considered critically, as the Ministry of Environment strongly supports shale gas production and as learned from past actions always tries to shape regulation in a way to speed up the commercial production by attracting new investors. Hence, this might be a further attempt by the state to achieve its goal by silencing and calming down internal opponents. On the other hand, this can also be an indication of a learning process by the government that might re-expand the window of opportunities for the Polish shale gas industry soon.

\section{Conclusion}

In conclusion, this paper basically analysed why until now the development of a shale gas industry in Poland is still stocking by covering critical aspects of the legal framework in combination with the policy background, the relations between government and business and socio-economic impacts. Basic sources of concern include a difficult geology in Poland combined with an uncertain regulatory environment. The illustrated delay in assessment of the actual amount of reserves still leaves Poland in doubt whether the industry could ever be commercially viable. Several foreign operators have withdrawn from Poland, which makes the situation for the government and the prospect to become a successful actor and achieve independence from Russia more disappointing and at the same time very keen.

It has to be pointed out, that the government acted too hasty and blindfold in the past when it comes to licensing. This already started in 2007, when the first licenses have been awarded to investors. Generally, a government would not grant any licenses without control and even for almost free, but being in the position of the Polish government, which is still in an urgent need of the expertise of foreign companies, it was not surprising that in 2007 licenses were granted to foreign firms without any guarantee of control with regard to the exploration and almost for free for around 100 Euros per square kilometre. This was probably the only appropriate strategy to conduct at this stage in order to capture important investors.

Nevertheless, the Polish government did one crucial mistake in this context. It granted all 115 available licenses in the same manner. It would have been done better by having employed this strategy in a limited fashion up to a certain amount. The consequence of Poland's mistake is basically the lost control over the ownership of the licenses. ExxonMobil for instance just moved to Ukraine and Russia and might now share gas deposits with its Russian counterpart (Jędrysek, 2013). The likelihood of this case is questionable, but the risk is present that they share shale oil fields located in Poland. The Polish government did plenty of mistakes in its attempt and enthusiasm to establish a footprint in that industry. It tried to shape the rules in an incremental way and tried to exclude local NGOs from the participation in decisions concerning shale gas exploration. It does not only put politics ahead of every other business, but even ahead of its own people. Trust in authorities of state collapsed. Thus, the results of its blind action in its ambition to become independent of Russia are 
significant - financial losses and broad economic and social negative effects. As a consequence Poland still does not have any idea how much oil and gas the country can provide. Clear indications with regard to efficiency, geology and appropriate technologies are still lacking.

Looking to the future, prospected impacts of a gas market liberalization in Poland stated in this paper emphasise that such a business appears to most essential for the country. Hence, efforts are expected to be made by applying the principle of economic optimization. Making Poland become independent of foreign gas supply - in addition to its potential future role as a gas provider for the European market itself - considerably addresses the dynamic of the resource-power-interdependence: Taking over a lead role in the unconventional gas extraction and production will seriously contribute to strengthen Poland's political importance across Europe.

Without any modification of the hydrocarbon law, business planning for investors will remain problematic. Shale gas explorers are - though impatient - waiting for changes in legislative by the Polish government. Moreover, the Polish government will have to follow the obligations of European legislation for the internal market of gas. In consideration of the fact that Polish officials seem to be the only advocates in Brussels, the European Commission also should invest effort in motivating Poland to implements demanded legislation as soon as possible.

If the Polish government continues distracting urgently needed foreign companies with expertise in shale gas exploration activities, generating advantages and benefits and becoming a leader in the unconventional gas extraction and production will almost be impossible and a development of the desired shale gas industry will further slow down. This future prospect highlights the interdependence between resource and power.

\section{References}

aktivist.pl. (2013, March 19). Poland proposes controversial shale gas regulations. Retrieved July 20, 2013, from http://www.wbj.pl/article62224-poland-proposes-controversial-shale-gas-regulations.html

Automated Trader. (2012, November 21). Poland to ignore European Parliament objections on shale gas drilling. Retrieved July 20, 2013, from http://www.automatedtrader.net/real-time-dowjones/119073/poland-to-ignore-european-parliament-objections-onshale-gas-drilling

BBC News. (2013, May 8). North American firms quit shale gas fracking in Poland. Retrieved July 20, 2013, from

http://www.bbc.co.uk/news/business-22459629

Cleantech Poland. (2013, April 16). Concern in Poland over shale gas regulations. Retrieved July 19, 2013, from

http://shalegas.cleantechpoland.com/?page =news\&id=61\&link=concer n-in-poland-over-shale-gas-regulations

Cleantech Poland. (2013, June 13). Polands eases state's role in shale gas concessions. Retrieved July 19, 2013, from http://shalegas.cleantechpoland.com/?page=news\&id=68\&link=poland -eases-state-s-role-in-shale-gas-concessions

E\&P News. (2012, November 13). Polish shale lobby says proposed law may hamper development. Retrieved July 20, 2013, from http://www.rigzone.com/news/oil_gas/a/122063/Polish_Shale_Lobby Says Proposed Law May Hamper Development

Goclowski, M. \& Kahn, M. (2014, Aprì 14). France's Total fails to renew Polish shale licence - ministry. Retrieved April 14, 2014 from http://af.reuters.com/article/commoditiesNews/idAFL6N0N627820140 414

International Energy Agency (2013). Poland: Statistics. Related Graphs. Share of total primary energy supply in 2009. Retrieved from http://www.iea.org/stats/pdf graphs/PLTPESPI.pdf(2013/07/18).

Jędrysek, M.-O. (2013, May 14). Shale gas in Poland: why companies abandon exploration? Retrieved July 18, 2013, from http://morion.salon24.pl/507235, shale-gas-in-poland-why-companiesabandon-exploration
Johnson, C., \& Boersma, T. (2012, November 27). Energy (in)security on Poland the case of shale gas. ELSEVIER (53), pp. 389-399.

Kosciuszko Institute (2011). Unconventional Gas - a Chance for Poland and Europe? Analysis and Recommendations. Retrieved from: http://ik.org.pl/test/cms/wp-

con-

tent/uploads/2011/09/Kosciuszko_Institute_UCG_report_29.08.2011.p df $(2013 / 07 / 11)$

Kosciuszko Institute (2012). The impact of shale gas extraction on the socio-economic development of regions - an American success story and potential opportunities for Poland (Abstract). Retrieved from: http://ik.org.pl/test/cms/wp-

content/uploads/2012/08/KI_ABSTRACT_The-impact-of-shale-gasextraction-on.pdf $(2013 / 07 / \overline{1} 8)$

KPMG (2012). Central and Eastern European Shale Gas Outlook. Retrieved from:

http://www.kpmg.com/HU/en/IssuesAndInsights/ArticlesPublications/

Documents/KPMG-CEE-Shale-Gas-Outlook.pdf(2013/07/12).

McClatchy. (2013, January 24). Poland strumbles as shale gas industry failed to take off. Retrieved July 20, 2013, from

http://www.mcclatchydc.com/2013/01/24/180933/poland-stumbles-asshale-gas-industry.html\#.UepFLazAEdp

Ministry of Treasury. (2013, April 19). Shale gas in Poland. (P. P. Agency, Ed.) pp. 1-4.

Minsitry of Environment. (2013, July 12). The campaign "Let's talk about shales" launched. Retrieved July 18, 2013

Natural Gas Europe. (2013, April 1). Poland proposes restrictions to shale gas opposition. Retrieved July 19, 2013, from http://www.naturalgaseurope.com/poland-proposes-restrictions-toshale-gas-opposition

Natural Gas Europe. (2013, June 3). Shale Gas a National Priority, says Polish Treasury Minister. Retrieved July 20, 2013, from http://www.naturalgaseurope.com/poland-new-treasury-ministerkarpinski-shale-gas-national-priority

occupy the pipeline. (2013, June 9). Poland Farmers Stand Up Against Chevron to Fight Fracking. Retrieved July 19, 2013, from http://occupythepipeline.blogspot.de/2013/06/poland-farmers-standup-against-chevron.html

Polskie Radio. (2012, April 11). New European shale gas regulations 'not needed' says Polish report. Retrieved July 20, 2013, from http://www.thenews.pl/1/12/Artykul/96026,New-European-shale-gasregulations-not-needed-says-Polish-report

Press Europ. (2012, March 22). End of shale gas El Dorado? Retrieved July 20, 2013, from http://www.presseurop.eu/en/content/newsbrief/1670421-end-shale-gas-el-dorado

PUNCH. (2012, October 4). ConocoPhillips lets Poland shale option lapse. Retrieved July 20, 2013, from http://www.punchng.com/business/energy/conocophillips-lets-polandshale-option-lapse/

Reuters. (2011, September 28). Poland may veto EU anti-shale gas moves. Retrieved July 20, 2013, from http://www.reuters.com/article/2011/09/28/poland-shale-vetoidUSL5E7KS13820110928

Reuters. (2013, May 14). Poland to adopt bill making shale gas push investor friendly-minister. Retrieved July 19, 2013, from http://www.reuters.com/article/2013/05/14/poland-shale-foreignidUSL6N0DV1EN20130514

The Economist. (2011, June 23). Energy in Poland. Retrieved July 17, 2013, from

https://zoterofilestorage.s3.amazonaws.com/66cd6c3088f4f6fcde2282 $885420 f 3 a a / E C O N O M I S T \% 20$ Energy\%20in\%20Poland_\%20Frackin g\%20heaven\%20_\%20The\%20Economist.pdf?AWSAccessKeyId=A KIAI4IEEOCQFLSM5GMQ\&Expires $=1374069769 \&$ Signature=Tmg NJ8CYXBmTndY0c1hK20U\%2BtZw\%3D

US Energy Information Administration (2013). Overview data for Poland. Natural Gas. Consumption. Retrieved from: http://www.eia.gov/countries/country-data.cfm?fips=PL\#ng $(2013 / 07 / 18)$

Warsaw Business Journal. (2013, June 6). Chevron withdraw from Poland? Retrieved July 20, 2013, from http://www.wbj.pl/article62954-chevron-to-withdraw-from-poland.html 